\title{
Democracy and Right to Freedom of Expression: A Case Study on the Nigerian Youth Protest on Police Brutality
}

\author{
Okoye Blossom Chisom \\ The University of Port-Harcourt, Port-Harcourt, Nigeria \\ Email: blossomokoye624@gmail.com
}

How to cite this paper: Chisom, O. B. (2021). Democracy and Right to Freedom of Expression: A Case Study on the Nigerian Youth Protest on Police Brutality. Open Journal of Political Science, 11, 34-53. https://doi.org/10.4236/ojps.2021.111004

Received: November 25, 2020

Accepted: January 10, 2021

Published: January 13, 2021

Copyright ( 2021 by author(s) and Scientific Research Publishing Inc. This work is licensed under the Creative Commons Attribution International License (CC BY 4.0).

http://creativecommons.org/licenses/by/4.0/

\section{(c) (i) Open Access}

\begin{abstract}
It is stated that both under the constitution of Nigeria and under the African Charter on Human People's Rights, persons in any part of Nigeria have the fundamental human right to privately and publicly freely express their disproval or objection over an issue through a protest any time or day. In history, protests have often inspired positive social change and improved protection of human rights, and they continue to help define and protect civic space in all parts of the world. In a democratic Nation like Nigeria, Protests encourage the development of an engaged and informed citizenry and strengthen representative democracy by enabling direct participation in public affairs. They enable individuals and groups to express dissent and grievances, to share views and opinions, to expose flaws in governance and to publicly demand that the authorities and other powerful entities solve problems and are accountable for their actions as seen in the case of the Nigeria Youths protest on police brutality. Yet governments around the world too often treat protests as either an inconvenience to be controlled or a threat to be extinguished. In a democratic Nation, the right to freedom of expression which could come through peaceful protests, involves the exercise of numerous fundamental human rights, and it is essential for securing all human rights, which the citizens should not be denied off by any person in power.
\end{abstract}

\section{Keywords}

Democracy, Freedom of Expression, Human Rights, Constitution, Protest, Police Brutality

\section{Introduction}

\subsection{Background of the Study}

One of the beauties of democracy is the rule of law. Human rights are protected 
under the most current constitution of 1999. Nigeria has made major improvements in human rights under this constitution through the American Human Rights Report of 2012 notes areas where significant improvement is needed, which include: abuses by Boko Haram, killings by government forces, lack of social equality, and issues with freedom of speech. In the period between its independence in 1960 and 1998, Nigeria had, in terms of heads of State, two elected, one appointed, one military successor and 7 [coups d'état] powers. In 1979, Nigeria adopted a presidential system in order to properly instate the right of choosing who rules them with a new constitution. This constitution guarantees fundamental human rights that are constantly in violation. Nigerian youths embarked on peaceful protest tagged \#EndSARS to demand the disbandment of the Special Anti-Robbery Squad (SARS) unit, as well as, other reforms in the Nigerian Police Force (NPF). What started out as a peaceful demonstration by thousands of youths, degenerated into chaos after the protests were hijacked by hoodlums. The hijacked protest is now characterized by the heavy presence of security personnel on the streets of Lagos, mob attacks on security personnel, killings, and vandalization of public and private properties. Oct. 20, 2020, will forever be known as Black Tuesday in Nigeria. In a darkness broken only by the blue light of cell-phone screens, the sound of gunshots rang out as the army and police allegedly fired into a crowd of young people who had gathered at Lagos's Lekki toll gate to protest against the now disbanded Special Anti-Robbery Squad (SARS), a notoriously abusive arm of the police. The massacre at Lekki punctuated more than two weeks of protest of police brutality in Nigeria. The hash tag \#EndSARS began trending (again) on social media on Oct. 4. The immediate trigger was a video that showed a SARS officer shooting a young motorist in Ughelli, in Delta state, then pushing his body out of the car and driving off with the dead man's Lexus SUV. Within days, crowds of young people gathered in Nigerian cities to demand the abolition of SARS. This year's protests follow on previous activism and government announcements that SARS would be demobilized in 2014, 2015 and 2017. And yet, SARS officers continued to act with impunity, committing armed robberies, rapes, other acts of torture and extrajudicial killings like the one in Delta State. On Oct. 11, leaders announced that SARS would be disbanded, but crowds of protesters grew bigger-even in the face of violence and intimidation. Since the protests began, estimates are that at least 100 individuals have allegedly lost their lives; 48 of whom were killed on Black Tuesday alone. Black Tuesday is the latest in a long history of police and military campaigns in Nigeria against the civilian population. For half of the republic's 60 -year history and for the century of colonial rule before independence, there have been quasi-military police forces and outright military police charged with repressing dissent from the civilian population. The history of Nigeria's police abuses helps us see the continuities in the misuse of state power against citizens. But it also shows that through it all, Nigerians have resisted the negation of their basic humanity and their rights to freedom of expression have been punctured. 


\subsection{Statement of the Problem}

Amongst different varieties of governments or regimes, democratic government is the greatest upholder and respecter of human rights. As such, expression of human rights blossoms most in a democratic setting. In Nigeria, democratic practice and its consequent protection of human rights are not what they ought to be. The flagrant violation of human rights in democratic Nigeria by so many governmental agencies casts doubt on the facility of real democratic practice in Nigeria. Respect for human rights enriches democracy and makes it the best option among many others. The Nigerian democracy is stripped of its one of its beauties, (upholding human of rights), by the rulers and their cohorts. Citizens are now restricted from having peaceful protests on the streets, at worst cases military men are alleged to start shooting at unarmed citizens if by any means the rulers of the nation feels threatened by the protesters, which in most cases such allegations are also denied by them. These government officials see themselves as above the law and have no regards for due process and rule of law. The immunity clause in the 1999 Nigerian constitution is an aberration of real democratic practice. People should be answerable for both their actions and inactions immediately and not after vacating offices. However, in Nigeria, this seems not to be the case as little or nothing is done about corruption and insecurity in the country.

\subsection{Aim of Research}

The aim of this research is to establish the correlation between democracy and fundamental human rights which the right to expression is encompassed in. This paper is of the notion that citizens in a democratic nation should be not be denied of the right to freely express their dissatisfaction or disapproval of governmental decisions or actions through peaceful protests, which is a platform whereby their views on issues on ground are aired, especially in an a democratic country.

\section{Ease of Use}

\subsection{Understanding Democracy}

Ozoigbo (2017) states that Democracy from the time of the ancient Athenians to the contemporary period has been regarded as a people oriented kind of government. This notion is gotten from its etymological derivation-"demos and Kratos", meaning rule or government by the people. In the view of Sabine \& Thorson (1973), the Greek Euripides clearly posited a democratic state as one that is ruled by the people through their representatives who are answerable to them. They went further to note the position of Rousseau in this regard as the government of the people for the General Will. This simply implies that the action of the government must be in fulfillment of The Will of the people which naturally is their welfare. As a matter of fact, the government must abide by the rule of law and make available to the people a system of education that will in- 
culcate in the children the idea that the idea of the realization of their individuality resides in their affiliation with the state, a kind of citizenship education. Appadorai (2003), thought of democracy as a system of government under which the people exercise the governing power either directly or through representatives periodically elected by themselves. Akinsanya (2000), in his own contribution maintained that democracy not only means a form of government in which the people rule in contradistinction to monarchies, aristocracies and gerontocracies; it also entails a state in which there is some form of political equality among the people. He went on to state that the central pillar of democracy the world over is based on the control of government by the people through free elections and universal adult suffrage. Therefore, only a democratic government, established by the consent of the governed in accordance with their shared values, has the moral authority to act as the legitimate agent of the people. Thus, democracy has been defended on the grounds that it achieves a number of fundamental values and goals; equality, liberty, moral self-development, the common interest, private interests, social utility, the satisfaction of wants and efficient decision. For authentic democracy to be on ground there must be as a matter of utmost necessity an independent electoral umpire, a strong and vibrant judiciary, an enlightened populace, a robust and free press, democratic culture and atmosphere of peace, and security. Coming home to Nigeria in terms of democratic practice, we assert that the primary instrument of democracy today is the 1999 constitution as amended. From 1999 till date, the question we always ask is, do we really have real democratic government or civilian government and what is real or consolidated democracy? To the first question, the obvious answer is no democratic government since the basic features of democracy are not present. These features are contained in the definition of consolidated democracy which Akinsanya (2000), said is measured by the extent to which a country has regular and fair elections, genuine contestation over selection (or election) of leaders and the choice of policy outcomes and citizenship participation in the electoral process. As a matter of fact, the regimes that took over power since 1999 cannot be called consolidated democratic regimes if we use the constitution as a guide, this entails measuring their performances using as yardstick by-products of consolidated democracy such as predictability, transparency, accessibility, adherence to constitutionalism and the "rules of the game", respect for human rights and the rule of law, public accountability and the system of checks and balances. It is really unfortunate that after almost eighteen years of democratic experimentation in Nigeria democratic values have not been established. What one notices everywhere is civilian dictatorship which manifests itself in flagrant violation of human rights of the ordinary citizens of this country. The concept of separation of power which lubricates democracy is a mirage in Nigeria. The "executive" flexes its muscles arbitrarily and always cows both the "legislative" and the "judiciary" and reduces them judiciary to mere puppets. In Nigeria the legislature and the judiciary are simply the "will" of the executive. 


\subsection{The Conceptualization of Human Rights}

For Iwe (1986), the issue of human rights cuts across ages and epochs-from the Greek world through the Roman, Medieval, Modern and Contemporary periods. And conscious and awareness of them continued to increase as the years go by, likewise their development and interpretation. Ojo (2006) was more specific in his attempt to trace the origin of the concept. For him, human rights are often traced to the stoics of the ancient Athens. Zeno who was the founder of the stoic school of thought propounded the theory of natural law under which human beings were supposed to have natural rights. To prevent the violation of these rights that were "immortal" in a sense, efforts were made to legislate against their violation with impunity. According to Ogundele (1985), the year 1188 was very remarkable in the history of human rights because it was the year that happened to be earliest known efforts to enhance human rights by King Alfonso IX, who included the rights of accused persons to a regular trial and the right of inviolability of life, honor, home and property as part of human rights. However, this earliest attempt was limited to the nobles alone. In terms of the definition of human rights, it can be said that in spite of the abundant writings the concept has generated, the term human rights does not lend itself to a precise definition. Indeed, there has never been a generally accepted definition of human rights among jurists, other scholars and commentators. It is a concept that can be best described rather than defined (Ajomo, 1985). However, despite the problem of not having a generally accepted definition of the concept, the attempt of two scholars in talking about it impressed me a lot. For Humana (1983), it is laws and practices that have evolved over the centuries to protect ordinary people, minorities, groups and races from oppressive rulers and governments. Human rights are rights that are held by all human beings unconditionally, unalterably and they are inalienable. According to Aduba (2012), human rights as those rights that are the very nature of every human person, hence, they define and affirm their humanity, therefore, they exist to ensure that human rights remain sacred and guarantee that inhumanity and injustice are prevented or reduced. He went on to maintain that since these rights are inalienable, they are not to be taken away or given up and also they are indivisible, there is no hierarchy among rights and no right can be suppressed in order to promote another right.. These rights that are really inalienable to man are comprehensively noted by Iwe (1986), to include but not limited to the following: 1) the right to Life (the status of the conceived but unborn child), the right to live, the right to corporal integrity, the right to a decent and healthy standard of living; 2) the fundamental Social rights: the right of meeting and association, the right of freedom of movement and residence within the state, the right of emigration and immigration; 3 ) the fundamental Moral-Cultural rights: man's right to Respect and to his good name (reputation), the right to education, the right to learn and investigate the truth; 4) the right to free Choice of State of Life; the right to religious freedom, the right to a free choice of Profession/Occupation; 5) the fundamental Eco- 
nomic rights: the right to the use of material goods, the right to work, the right to a just and adequate remuneration, the right to possess and own; 6) fundamental Civil-Political rights: the right to equality, the right to equal legal protection, the right to take part in government. The 1999 Nigerian Constitution (as amended) seemed to derive much from Iwe's content of human rights in stating its own fundamental human rights that apply to every Nigerian citizen. These are the fundamental rights as enshrined in the 1999 Constitution. 1) Right to Life. Article 33 states that every person has a right to life and no one shall be deprived intentionally of his life save in execution of the sentence of a court in respect of a criminal offence of which he has been found guilty in Nigeria. 2) Right to Dignity of Human Person. Article 34 has it that every individual is entitled to respect for dignity of person and accordingly, no person shall be subjected to torture or to inhuman or degrading treatment. No person shall be held in slavery or servitude and no person shall be required to perform forced or compulsory labor. 3) Right to Personal Liberty. Article 35 requires that every person shall be entitled to his personal liberty and no person shall be deprived of such liberty save in the following cases and in accordance with a procedure permitted by law. 4) Right to Private Life. Article 36 prescribes that in the determination of civil rights and obligations including any question or determination by or against any government or another, a person shall be entitled to a fair hearing within a reasonable time by a court or other tribunal established by law and constituted in such a manner as to cure its independence and impartiality. 5) Right to Private and Family life. Article 37 says that the privacy of citizens, their homes, correspondence, telephone conversations and telegraphic communications is hereby guaranteed and protected. 6) Right to Freedom of Thought, Conscience and Religion. Article 38 states that every person is entitled to freedom of thought, conscience and religion, including freedom to change his religion or belief, and freedom (either alone or in community with others, and the public or in private) to manifest and propagate his religion or belief in worship, teaching, practices and observance. 7) Right to Freedom of Expression and the Press. Article 39 states that every person shall be entitled to freedom of expression, including freedom to hold opinions and to receive and impart ideas, information without interference. 8) Right to Peaceful Assembly and Association. Article 40 states that every person shall be entitled to assemble freely and associate with other persons, and in particular he may form or belong to any political party, trade union or any other association for the protection of his interests. 9) Right to Freedom of Movement. Article 41 has it that every citizen of Nigeria is entitled to move freely throughout Nigeria and to reside in any part thereof and no citizen of Nigeria shall be expelled from Nigeria or refuse entry thereto or exits therefore. 10) Right from Freedom from Discrimination. Article 42 holds that a citizen of Nigeria of a particular community, ethnic group, place of origin, sex, religion or political opinion shall not, by reason only that he is such a person be subjected either expressly by, or in the practical application of, any law in force 
in Nigeria or any executive or administrative action of government, to disabilities or restrictions to which citizens of other communities, ethnic group, places of origin, sex, religious or political opinions are not made subject. No citizen of Nigeria shall be subjected to any disability or deprivation merely by reason of the circumstances of his birth.

\subsection{A Glimpse at Human Right Situation in Nigeria}

Having seen the general contents of human rights and those enshrined in the Nigerian 1999 constitution as amended, we now situate it on the Nigerian society. We begin by stating very emphatically that no system of government guarantees respect for human rights more than that of a democratic government. Hence, when power shifted from the Military to the democratically elected government in 1999, Nigerians were full of confidence that human persons will now begin to enjoy these rights that are fundamental to them. However, Nigerians were shocked to observe that the violation of human rights that obtained during the Military dictatorship never abated. What we still have is gross violation of human rights with unprecedented crescendo in every aspect of it. In this paper just few instances of this violation are noted. Nigerians will not forget in a hurry what has been termed the "Odi Massacre". Odi is a town in Bayelsastate in the South South region of Nigeria where the inhabitants were agitating the way the Federal Government of Nigeria was going about the exploration of oil there which left their habitat inhabitable as a result of oil pollution. The Federal Government, democratically elected, led by Olusegun Obasabjo ordered the military to descend on the town on the $20^{\text {th }}$ November 1999, which left about 2500 civilians dead as reported by Human Rights Watch (accessed. Here the fundamental right of life has been violated by a government that supposed to be democratic. Not long after the seeming holocaust at Odi community, the Nigerian military once again ferociously descended on a town in Benue state called Zaki Biam on the 22nd October 2001. In this military display of brutality, about 100 civilians were killed from the Tiv ethnic community. Their offence was an alleged abducting and killing of 19 soldiers that were sent there to restore peace in that troubled region. There was crisis between the Tivs and Jukuns of that State and because the mutilated bodies of the slain soldiers were found in Zaki Biam community, the military called them for a meeting where they were killed and set ablaze - a clear violation of right to life. In February and May 2016, security forces were accused of killing at least 40 members of the Indigenous People of Biafra (IPOB) and Movement for the Actualization of the Sovereign State of Biafra (MASSOB). The groups were and are advocating for the separation of Biafra, mainly made up of Igbo speaking of the southeast and south-south and the release of Nnamdi Kanu, the IPOB leader detained and undergoing trial for treason since October 2015. According to World Report (2017), in the crude oil rich Niger Delta, media reports say that on September 8 2016, soldiers seeking to arrest members of the militant group-Niger Delta Avengers, destroyed 43 houses and other properties in Peremabiri, Akamabugo and Tikogbene communities of 
Bayelsa State and currently trending, the massacre of peaceful Nigerian youths who were allegedly shot at randomly at the Lekki toll gate of Lagos State Nigeria, by the Nigerian military Force on the $20^{\text {th }}$ of October, 2020. Despite all these noticed and noted human rights violation in a democratic Nigerian government, the one that goes on everyday but is not talked about is that of the dignity of the human person expressed in the right to descent environment. The violation is carried out by both the agencies of the government and ordinary citizens in different aspects. In democratic Nigeria it has become a common thing to observe with dismay incessant and unauthorized blaring of sirens by government and quasi-government officials and some ordinary citizens as well. Succinctly put, human rights violations especially that of Life and Human dignity by governmental agencies and private citizens, thrive in these instances obtained in Nigeria; menace of Boko Haram insurgency and other acts of terrorism, Militancy in the Niger Delta region, sKidnapping, Bribery and Corruption, Government insensitivity, Unemployment, Inflation, poverty, Police and Military brutality on civilians and the like, as noted by Ogoloma, et al. (2014).

\subsection{Connection between Understanding Democracy and the Conceptualization of Human Rights}

Democracy and human rights are grounded in the shared principles of accountability, individual liberty, integrity, fair and equal representation, inclusion and participation, and non-violent solutions to conflict. Modern conceptions of democracy are based on the fundamental ideas of popular sovereignty and collective decision making in which rulers through various ways are held to account by those over whom they rule (see Beetham, Carvalho, Landman, \& Weir, 2008; Landman, 2013). But beyond this basic consensus, there are many varieties of democracy (see Coppedge, Lindberg, \& Skaaning, 2016) or "democracy with adjectives" (Collier \& Levitsky, 1997) that have been in use by scholars, practitioners and policy makers. These definitions can be grouped broadly into three main types: 1) procedural democracy, 2) liberal democracy, and 3) social democracy, the delineation of which largely rests on the variable incorporation of different rights protections alongside the general commitment to popular sovereignty and collective decision making. Understanding these different types of democracy and the degree to which they incorporate different categories of human rights affects the ways in which measures of both can and have been used for empirical research (Landman, 2013, 2016; Landman \& Carvalho, 2009; Landman \& Häusermann, 2003). Absence of consideration of these lines of overlap has led to conceptual and empirical confusion in the literature on democracy and human rights, as well as in those studies that incorporate measures of either concept in their modelling strategies (sees Munck, 2009). Procedural definitions of democracy are most closely aligned with Robert Dahl's (1971) formulation in Polyarchy and include the two dimensions of contestation and participation. Contestation captures the uncertain peaceful competition necessary for democratic rule; a principle which presumes the legitimacy of a significant and organized 
opposition, the right to challenge incumbents, protection of the twin freedoms of expression and association, the existence of free and fair elections, and a consolidated political party system. Such a procedural definition of democracy can be considered a baseline set of conditions and a minimum threshold that can be used to assess and count the number of democracies in the world (see, e.g. Banks, 1971; Landman, 2013: pp. 3-5; Przeworski, Alvarez, Cheibub, \& Limongi, 2000). Liberal definitions of democracy preserve the notions of contestation and participation found in procedural definitions, but add more explicit references to the protection of certain human rights. Definitions of liberal democracy thus contain an institutional dimension and a rights dimension (see Foweraker \& Krznaric, 2000).

The institutional dimension captures the idea of popular sovereignty, and includes notions of accountability, constraint of leaders, representation of citizens, and universal participation in ways that are consistent with Dahl's "polyarchy" model outlined above. The rights dimension is upheld by the rule of law, and includes civil, political, property, and minority rights. Such a definition is arguably richer (or "thicker") as it includes legal constraints on the exercise of power to complement the popular elements in the derivation of and accountability for power (Coppedge, 2012: pp. 17-33). Social definitions of democracy maintain the institutional and rights dimensions found in liberal models of democracy but expand the types of rights that ought to be protected, including social, economic and cultural rights (although some of these are included in minority rights protection seen in liberal definitions) (Beetham, 1999; Brandal, Bratberg, \& Thorsen, 2013; Doorenspleet, 2005; Landman, 2005, 2013, 2016; Macpherson, 1973; Przeworski, 1985; Sørensen, 1993). This expanded form of democracy, extends "the democratic principle from the political to the social, in effect primarily economic, realm" (Przeworski, 1985: p. 7). In the terms deployed here, the concept of social democracy thus includes the provision of social and economic welfare and the progressive realisation of economic and social rights. It could also be argued that it includes the protection of cultural rights, which are concerned with such issues as mother tongue language, ceremonial land rights, and intellectual property rights relating to cultural practices (e.g. indigenous healing practices and remedies that may be of interest to multinational companies). In their modern manifestation, human rights have become an accepted legal and normative standard through which to judge the quality of human dignity (Landman \& Carvalho, 2009). This standard has arisen through the concerted efforts of thousands of people over many years inspired by a simple set of ideas that have become codified through the mechanism of public international law and realized through the domestic legal frameworks and governmental institutions of states around the world (Landman, 2005; Landman \& Carvalho, 2009). While the 1948 Universal Declaration of Human Rights makes reference to the right to take part in government (including through direct or indirect representatives, equal access to public services, and through periodic elections), the non-binding nature of the Universal Declaration of Human Rights along with a 
paucity of specific reference to democracy itself in subsequent international human rights instruments, means that human rights as such have been more legally codified through international human rights law than democracy. According legal recognition to the moral claim of human rights through international law means that states are legally obliged to ensure that they respect, protect, and fulfil these claims (see, e.g. Koch, 2005). There is no corresponding legal obligation to respect, protect, and fulfil democracy in the same way as there is for rights, which provides a stronger foundation and core content for human rights than for democracy. As we shall see empirically, however, democracy is a form of government that appears superior to other forms of government for protecting, respecting and fulfilling human rights obligations. Respecting human rights requires the state to refrain from violating them. Protecting human rights requires the state to prevent the violation of human rights by "third" parties, such as private companies, non-governmental organisations, paramilitary and insurgency groups, and "uncivil" or undemocratic movements. Fulfilling human rights requires the states to invest in and implement policies for the progressive realisation of human rights (Koch, 2005; Landman \& Carvalho, 2009; Landman \& Kersten, 2016). Civil and political rights protect the "personhood" of individuals and their ability to participate in the public activities of their countries. Economic, social and cultural rights provide individuals with access to economic resources, social opportunities for growth and the enjoyment of their distinct ways of life, as well as protection from the arbitrary loss of these rights. Solidarity rights seek to guarantee for individuals access to public goods like development and the environment, and some have begun to argue, the benefits of global economic development (Landman, 2006; Landman \& Carvalho, 2009). Taken together, there are now a large number of human rights that have been formally codified, which can be enumerated from the different treaties that have been designed to protect them. In following Beetham (1999: p. 94) and the brief discussion of democracy and human rights, it is clear that different conceptions of democracy vary precisely around the question of the degree of overlap and interaction between the institutional and rights dimensions. Beetham (1999: p. 94) visualises this overlap as a Venn diagram with democracy in one circle and human rights in another, where different definitions and conceptualisations of democracy necessarily reflect smaller and larger degrees of overlap. Thin or procedural definitions of democracy afford less space for human rights than thicker or social definitions, while it may be possible to conceive of some attributes of human rights sitting outside the conceptual space of democracy. By thinking of the association between democracy and human rights in this way, Beetham (1999) avoids the problem that democracy and human rights might be construed as mutually constitutive of one another while retaining the notion that they are "inter-dependent and mutually reinforcing". Hill (2016) makes the case that respect for personal integrity is a sine qua non for the existence of democracy and argues that democracy and human rights are thus mutually constitutive. In the terms set out here, however, Hill's (2016) argument only focuses on 
physical integrity rights, which means that his conception of democracy sees a permanent overlap between the institutional dimension of democracy and this more limited set of human rights, which typically include freedom from torture, arbitrary detention, extra-judicial killing, and exile (see Poe \& Tate, 1994). It is not clear from the literature on democracy or human rights that human rights beyond this more limited set are indeed necessarily part of the concept of democracy. Where Hill (2016) is correct is with respect to the endogeneity problem in the empirical analysis of the relationship between democracy and human rights as we shall see in subsequent discussions below. The possibility of different definitions and different degrees of overlap necessarily affects the ways in which both concepts are measured and analyzed (Coppedge, 2012); however, there has not been much discussion about this particular issue in the measurement literature (see Munck, 2009), since there are discussions on the measurement of democracy or human rights, but not democracy and human rights. Moreover, discussions of the measurement of democracy, as well as the empirical operationalisation of democracy include measures that are arguably more about human rights than democracy per se. Helliwell (1994) combines these two Freedom House measures arithmetically and calls the combination an "index of democracy", a move which necessarily commits him to a specific concept of democracy and inclusion of some human rights but not all.

\subsection{Democratic Freedom of Expression}

This section progressively descends from some proposed aspects of democratic theory to the proposed conception of the right of freedom of expression. The democratic freedom of expression starts by recognizing that everyone's human rights are the same and must consequently be given equal consideration. In giving people's human rights equal consideration, attention must be given to whether there is domination in the relations that exist in society. When there is domination, it is legitimate to intervene to abolish it. The freedom that comes with individual and collective autonomy entails responsibility. Thus, liberty is not an arbitrary power, but an accountable one. The democratic state is an effective instrument for protecting and fomenting human rights, abolishing domination. Such a state exemplifies the democratic ideal of equal consideration in the vote, whose spirit is the supremacy of the public interest over powerful religious, royal, military, capitalist, party or other special interests. The natural application to the right of freedom of expression is that everyone has this right equally and that this right comes with the responsibility to respect the rights of others. When expression is an instrument of domination, it is outside the scope of this right, it infringes on the rights of others, which must be given equal consideration, and it is necessary to hold the agent that propagated the expression responsible by standards of justice. A very good system for giving everyone equal consideration is the democratic one. This practice is designed to approximate the principle of affected rights. The rights-based approach has it that voting is designed to approximate the principle that people whose rights are at stake in a matter are the 
ones who should participate in the decision-making process associated with it. Rights have the rights of others as their common boundary and transgression of these boundaries is an act of domination. Rights are legitimate liberties, which are the kinds of liberties worth protecting and fomenting, and are consequently the kinds of liberties we refer to below. Here, the degree to which there is liberty in a population is inversely proportional to the degree to which there is domination.

\subsection{The Nigerian End SARS Protest: Government Intervention and Its Relation to Democracy and Freedom of Expression}

\subsubsection{The Birth of the End SARS Protest}

According to Wikipedia, End SARS is a decentralized social movement, and series of mass protests against police brutality in Nigeria. The slogan calls for the disbanding of the Special Anti-Robbery Squad (SARS), a notorious unit of the Nigerian Police with a long record of abuses. The protests which takes its name from the slogan started in 2017 as a Twitter campaign using the hash tag \#ENDSARS to demand the disbanding of the unit by the Nigerian government. After experiencing revitalization in October 2020 following more revelations of the abuses of the unit, mass demonstrations occurred throughout the major cities of Nigeria, accompanied by vociferous outrage on social media platforms. About 28 million tweets bearing the hash tag have been accumulated on Twitter alone. Solidarity protests and demonstrations by Nigerians in Diaspora and sympathizers occurred in many major cities of the world. The protests are notable for its patronage by a demographic that is made of entirely young Nigerians. The movement has since expanded to include demands for good and accountable governance. SARS officers have been alleged to profile young Nigerians, mostly males, based on fashion choices, tattoos and hairstyles. They were also known to mount illegal road blocks, conduct unwarranted checks and searches, arrest and detain without warrant or trial, rape women, and extort young male Nigerians for driving exotic vehicles and using laptops and i-phones. Nigerians have shared both stories and video evidence of how officers of SARS engaged in kidnapping, murder, theft, rape, torture, unlawful arrests, humiliation, unlawful detention, extrajudicial killings and extortion of Nigerian citizens. A large section of the victims of the abuses of SARS have been young male Nigerians.

\subsubsection{Report on How Peaceful Protesters Were Allegedly Shot at}

A report from shola Lawal and Monic Park which was published on the New York Times states as thus:

"LAGOS, Nigeria-With music playing and food being passed around, a festive atmosphere hung over the protest encampment on Tuesday night, despite the anger over police brutality that in recent weeks had driven youthful demonstrations that were the biggest Nigeria had seen in a generation. As darkness fell, Nigerian flags were handed out among the thousands of people gathered there. Philip Agu, a sound engineer who had volunteered to run the huge speaker sys- 
tem, said a protest leader took the microphone and told the crowd that the police would likely arrive soon, but that if they sat down, sang the national anthem and waved their flags, they would face no danger. The speaker told the crowd, Mr. Agu recalled, that all around the world, "No soldier can shoot any citizen holding their own national flag." Three hours later, dozens of people were hit by gunfire from security forces, some fatally, and images of bloodied protesters and their bloodied flags strewn on the ground flooded the social media accounts of millions of Nigerians. Survivors recalled a sudden shift from sitting peacefully to fleeing in panic. Some said military and police units surrounded the demonstrators in the affluent suburb of Lekki, preventing them from leaving.

"I thought I was going to die," said Kolade Abiola Ahmed, his voice still quaking a day later.

Soldiers and police officers opening fire on unarmed youths in an upscale neighborhood shocked the nation, even older citizens who recalled growing up under a series of military dictatorships. The protests over police brutality in the past two weeks had been larger and even more widespread than the last round of major demonstrations, in 2012, after the government stopped subsidizing fuel, but they had remained largely peaceful. Nigeria's security forces have long been criticized for human rights abuses, particularly in the impoverished northeastern region, but there was a different set of victims this time. Many of the demonstrators have been middle-class, well-educated young people in the southern and central cities, better off than earlier generations, and too young to remember military rule that ended in 1999. Their movement, like Black Lives Matter in the United States, has been youth-driven, mostly leaderless and propelled by social media-a nimble, amorphous force that has been hard to quell. On Tuesday, the security forces killed at least 12 people at demonstrations in the Lagos area, including 10 at Lekki, Amnesty International reported on Wednesday. "These shootings clearly amount to extrajudicial executions," said Osai Ojigho, the group's director for Nigeria. "There must be an immediate investigation and suspected perpetrators must be held accountable through fair trials." The government did not give casualty figures, but a police officer under the Lagos State Command Area Alpha headquarters, who was at the scene of the killings, told The New York Times on Wednesday that at least 11 people had been killed.

On Wednesday, some of the protesters were out in the streets again, violating a 24-hour curfew imposed the day before and newly aware that they could be risking their lives. Plumes of smoke rose from at least three buildings, including one that houses TVC News, which stopped broadcasting. Sporadic gunshots could be heard around Lekki and Yaba, districts 20 miles apart, separated by a lagoon. Calling themselves the "SoroSoke" or "speak up" generation in the Yoruba language widely spoken in Lagos, the nation's largest city, the protesters have insisted that a notorious police unit, the Special Anti-Robbery Squad, be disbanded, and its most brutal officers prosecuted. The unit, known as SARS, has earned a reputation for abusing, torturing and even killing young people; an Amnesty report in June referred to its "horrific reign of impunity." 


\subsubsection{Governmental Response and Intervention}

The President of the Federal Republic of Nigeria, President Muhammadu Buhari-a former army general who led a military government in the 1980s-vowed last week to disband SARS. But there was no word on prosecutions, and government officials indicated that the officers would simply be moved to other units, not dismissed. Protesters denounced the changes as window-dressing. On Tuesday, reports of police killing people, followed by the burning of a police station, prompted the governor of Lagos state, Babajide Sanwo-Olu, to declare a 24-hour curfew. He said that people bent on chaos had hijacked the peaceful protests. Despite the curfew, the demonstrators near the Lekki tollgate did not disperse. Mr. Ahmed, who had been attending protests since Thursday, said people remained seated on the ground, chanting slogans and waving their flags, as at least a dozen trucks arrived with police and military units. There were already ominous signs. Witnesses reported seeing people dismantle streetlights and remove security cameras that would have recorded what was to come next. Many protesters contend that the government has used paid provocateurs to sow violence, as an excuse for a brutal crackdown. The police officer who confirmed the deaths said that he and dozens of others were ordered to head to the Lekki protest at around 7 p.m. They piled into 15 Toyota pickup trucks, he said, joined by at least three Tata trucks full of soldiers. Some demonstrators were armed, and others threw rocks at the uniformed forces, according to the officer, who spoke on condition of anonymity because he was not authorized to discuss the matter. But other witnesses said that without warning or provocation, the security forces began shooting into the air, and then at the civilians trying to flee in terror. "They were trying to circle us, put us in the middle, they were spreading out and they were trying to go around so that we would be in the middle," said Eti-Inyene Akpan, a 26-year-old photographer who was there. Many people, including Mr. Akpan and Mr. Ahmed, took shelter behind barricades and under parked cars. "There was a lady who excreted because of fear," Mr. Ahmed said. Video streams on social media showed wounded people lying in the streets, or being carried by others into teeming hospital emergency rooms. The national government has been all but silent on what happened Tuesday night. Mr. Buhari appealed for calm. In a televised statement on Wednesday, the governor, Mr. Sanwo-Olu, sought to distance himself from the security forces deployed on Tuesday, and said he had ordered an investigation into the "rules of engagement" they adopted. "This is with the view to taking this up with the higher command of the Nigerian Army and to seek intervention of Mr. President" he added. The curfew was extended by three days, until Saturday. The bloodshed drew international condemnation, and not only from human rights groups. Joseph R. Biden Jr., the Democratic presidential candidate and former vice president, and Hillary Clinton, the former secretary of state, and also international entertainment celebrities such as Beyoncé and Justin Bieber, called on the authorities to halt the violent crackdown. Despite the violent response, the protest 
movement will not go away, demonstrators and analysts said. "The movement is succeeding while others have failed because of the format it adopted, both offline and online," said Idayat Hassan, director of the Centre for Democracy and Development, a policy research group in Nigeria. "The hash tag has helped them to garner international support but importantly to galvanize the young people." For his part, Mr. Ahmed was back on the streets and protesting on Wednesday, fueled by anger at being shot. He and a small group first marched to the gates of a house belonging to the governor's family. "I was shouting his name to come out," Mr. Ahmed said. "He doesn't care even if I was killed or my friends were killed, too, and he says he is a leader." According to a report from an African reporter, Yomi Kazeem which was published on QUARTSAFRICA, Two weeks after \#EndSARS protests against police brutality began, president Muhammadu Buhari finally gave a national address. But what should have been an opportunity to unify the country and, more significantly, empathize with grieving families, proved to be anything but. Keeping with his long-running style as a former military general and dictator, president Buhari's speech came off instead as high-handed and tough.

Most notably, the president's speech, which was pre-recorded, made no mention of troubling events at Lekki toll gate in Lagos on Oct. 20 when numerous witnesses say Nigerian soldiers fired into a crowd of peaceful, unarmed protesters who had remained at the toll gate following a hastily announced curfew. The shootings resulted in several injuries and left seven dead, according to Punch, a major local newspaper. The president's decision to completely omit the Lekki shootings from his speech was in line with the army's official stance of denial despite a wealth of video footage which contradicts this claim. President Buhari's speech also came with a demand-and a thinly veiled threat-for protesters to call off street demonstrations which have seen thousands gather at different locations across the country while using digital tools to drive and sustain momentum .These threats, goes against the right to freedom of expression especially as a democratic Nation "In the circumstances, I would like to appeal to protesters to note and take advantage of the various well-thought-out initiatives of this administration designed to make their lives better and more meaningful, and resist the temptation of being used by some subversive elements to cause chaos with the aim of truncating our nascent democracy," Buhari said. "For you to do otherwise will amount to undermining national security and the law and order situation. Under no circumstances will this be tolerated," he added. The national address sought to amplify the government's responses to the demands of protesters, including disbanding the rogue special anti-robbery police unit that is infamous for extortion and extra-judicial murder. But recent evidence provides little reason to trust that an announcement of the unit's disbandment will translate into less harassment for young Nigerians who are often targeted. In fact, the latest announcement is the fourth time the police leadership has placed restrictions on the unit's operations in four years. In some ways, that Buhari gave a speech was a novelty in itself. Through his five years in office, Nigerians 
have mainly heard from the president during national holidays or through interviews granted to foreign media.

Yet, the strongest indictment of the president's speech is that most young Nigerians expected little from it in the first place. After a successful presidential campaign in 2015 that aimed at endearing the president to younger Nigerians, his administration has since been criticized for being out of touch with and tone-deaf to an increasingly important youth demographic. "The first thing I wanted to hear yesterday was the president speaking with some empathy. I also expected him to clear up issues like why the military (or men in military uniform) were shooting unarmed civilians ... and show solidarity with the people." says Wale Agbede, a Lagos-based media professional who joined the protests. [But] my take away from that speech is that the president is cut off from the plight of the ordinary citizens. An investigation is said to still be ongoing by $\mathrm{CNN}$ as they strive to unveil the story behind the Shooting that happened at the Lekki Toll gate, Lagos State, Nigeria which had allegedly cost the lives of many Nigerian youths.

\section{Research Findings}

There is no denying that Nigerian Constitution contains very elaborate provisions granting fundamental rights to Nigerians. There is also no doubt that the said provisions were in conformity with international human right instruments with the aim of deepening democratic governance in the country. What has however raised concerns was the extent to which successive governments particularly the present government have promoted and observed the provisions. According to Jega (2008), the promotion of human rights involves making citizens know their rights, to be able to defend them, as well as know the rights of others, to be able to respect and not breach them. It also includes training of the law enforcement personnel and those involved in the administration of justice, to enable them show greater respect for other people's rights, and sensitivity and tact in handling human rights issues in their duties as public officers.

In a democracy, the rule of law protects the rights of individuals, preserves order, and limits powers of government. The reverse seems to be the case in $\mathrm{Ni}$ geria. Human rights are not respected. Extra-judicial killing, unlawful detention, and other series of human rights abuses are still prevalent. Ofoegbu (2013: p. 60) noted that the most significant human rights problems in Nigeria are extra-judicial killings and use of excessive force by security forces, impunity for abuses by security forces, arbitrary arrests, prolonged pre-trial detention, judicial corruption, and executive lawlessness and influence on the judicial system. The right of the people to freely express themselves is in jeopardy and police brutality and wanton abuse of court orders are concerning. The right to life granted Nigerians by the Constitution has been taken away and the society is daily regaled by reports of pogrom and fratricidal carnages meted to the people by Boko Haram (a group against western education), Fulani herdsmen and Police brutality. 
The Special Anti-Robbery Squad (SARS) in Nigeria was established to address insecurity and crimes in the nation. Rather than achieve their stated objective, they began profiling and harassing young people which led to wrongful arrests, brutalization and loss of innocent lives. In response to the recent deaths instigated by SARS officers, anti-SARS protests erupted across the nation and around the world. Two weeks later, 12 unarmed protesters were shot dead at Lekki Lagos State on October 20, 2020 by members of the Nigerian Army and Police, after the state declared a 24 hour curfew (as reported by Amnesty International),

In view of this tragic development, it is important to us that we create awareness of the human rights that protect Nigerians as contained in the Constitution of the Federal Republic of Nigeria 1999 ("CFRN"), the African Charter on $\mathrm{Hu}$ man and Peoples' Rights (“ACHPR”) and the United Nation's Universal Declaration of Human Rights ("UDHR"); and its enforcements.

As seen in the report of the shooting that occurred at the Lekki toll gate, Lagos state, Nigeria, whereby Nigerian Youths who had come out unarmed in their masses to protest peacefully against Police brutality in the country were allegedly shot at, leaving many injured, and some dead during the End SARS Protest. However, the following rights listed in Table 1 were breached by the Nigerian security personnel's and the government had little or nothing to say about the incident but rather insisted that the protest be put to a stop without fully meeting the demands of the protesters.

Table 1. Constitutional fundamental human rights that were violated during the end SARS protest.

\begin{tabular}{|c|c|c|}
\hline $\begin{array}{l}\text { Fundamental } \\
\text { Human Right }\end{array}$ & Relevant Provision & Details \\
\hline Freedom of Expression & $\begin{array}{l}\text { Section } 39 \text { CFRN; art } 9 \text { ACHPR; } \\
\text { art } 19 \text { UDHR. }\end{array}$ & $\begin{array}{l}\text { These provisions grant every Nigerian the freedom to receive and express their } \\
\text { opinion, ideas and information. It also grants the right to establish and operate any } \\
\text { medium used in disseminating information in Nigeria subject to the regulations of } \\
\text { wireless broadcast. }\end{array}$ \\
\hline Freedom of Association & $\begin{array}{l}\text { Section } 40 \text { CFRN; art } 10 \text { and } 11 \\
\text { ACHPR; art } 17 \text { and } 20 \text { UDHR. }\end{array}$ & $\begin{array}{l}\text { Every Nigerian is entitled to form or join any association of people in Nigeria in } \\
\text { support of his interest. }\end{array}$ \\
\hline Right to Dignity of Life & $\begin{array}{l}\text { Section } 34 \text { CFRN; art } 4 \text { ACHPR; } \\
\text { art } 1,4,5 \text { and } 6 \text { UDHR. }\end{array}$ & $\begin{array}{l}\text { Every individual is entitled to dignity and respect. He is entitled to be free from } \\
\text { slavery and torture. }\end{array}$ \\
\hline Right to Liberty & Section 35 CFRN & $\begin{array}{l}\text { Every Nigerian has the right to personal liberty and no person should be deprived } \\
\text { of this right except: 1) in execution of a criminal sentence by a court of law; 2) for } \\
\text { failure to comply with an order of court; } 3 \text { ) in bringing him before a court; 4) in } \\
\text { preventing him from committing an offence; 5) where he is reasonably suspected of } \\
\text { committing an offence; and 6) for the purpose of care and treatment for persons } \\
\text { with infectious disease, unsound mind or addictions. }\end{array}$ \\
\hline Freedom of Movement & $\begin{array}{l}\text { Section } 41 \text { CFRN; art } 12 \text { ACHPR; } \\
\text { art } 13 \text { UDHR. }\end{array}$ & $\begin{array}{l}\text { Every Nigerian has the right to move anywhere in Nigeria. This right, however, } \\
\text { does not apply where a person has been lawfully sentenced to imprisonment or } \\
\text { restricted by a court of law. }\end{array}$ \\
\hline
\end{tabular}




\section{Conclusion}

Freedom of expression is one of the fundamental rights, which are universally recognized and protected. Freedom of peaceful assembly enables individuals to express themselves as part of a collective, including by engaging in public marches, protests, pickets and demonstrations. Assemblies can be platforms to advocate for change and for people to raise awareness about the issues that matter to them, whether it relates to human rights or otherwise. On this note, countries have an obligation to ensure that the right to freedom of assembly is protected as stated in Section 40 of the Nigerian 1999 constitution which gives the freedom of citizens of Nigeria to assembly freely and associate with one another. They cannot interfere with the right to peaceful protest assembly, simply because it disagrees with the protesters views, and must ensure that the right is enjoyed equally by all groups, without discrimination on any ground. Effective protection of the right to freedom of peaceful assembly strengthens democracies. It helps foster a culture of open democracy, enables non-violent participation in public affairs and invigorates discussions on important issues. Public assemblies also help to promote good governance by providing opportunities for the public to hold to account people of organizations with power, including corporate entities, public bodies and governmental officials. This work, having stated some cases of human rights violations by both government and private citizens, advocates faithfulness to statutory and constitutional responsibilities by all and sundry. Nigerians should know their rights and insist on them being respected without fear of intimidation, victimization and contradictions. The Mass Media, both electronic and print, should mobilize the people to live up to their obligations in order to rightly ask government questions and demand respect for human rights and reparation when abused. Nigeria with all her resources both natural and human should be a model for liberal democracy and rule of law that safeguards human rights. Human rights cannot be taken away in democracy, because democratic government exists to cater for the interest of the populace by safeguarding their fundamental rights. The imports of human rights are today underscored by elaborate provisions in the constitutions of states. In the case of Nigeria, the 1999 constitution as amended provides for the rights of Nigeria, however, serious and conscious attempt by the present government to abide by those provisions. It is therefore germane that the government takes proactive steps to properly sanitize the rights of the people of their rights. It is also necessary to re-orient the security agents by way of training to always respect the rights of Nigerians.

\section{Acknowledgements}

First and foremost, my gratitude goes to the Almoghty God for his infinite mercy throughout the completion of this research work.

A Special thanks to Associate Professor Levi, Obijiofor for his constant support towards this work. Sincere Gratitude's to the editors of this journal who has found this research paper worthy of publication. Also, I would like to thank 
Pastor Mrs Joy Ngozi Okoye, Mr and Mrs Christian Mbonu, Dr and Dr Izuchukwu Metu, Dr Allwell Okoye and Mr Divine Okoye for both their financial support and ideas to this work.

Finally, I am grateful to Mr Onyedikachi Obimma and Mr Odetunde Damilare Emmanuel for their intellectual support during this Project.

\section{Conflicts of Interest}

The author declares no conflicts of interest regarding the publication of this paper.

\section{References}

Aduba, J. N. (2012). Inquiries on Human Rights Practice in Nigeria, Past, Present and Future. Inaugural Lectures, University of Jos Lecture Series, 54, June 29.

Ajomo, M. A. (1985). Man in Quest of Himself: The Challenges of Human Rights. The 18th Convocation Lecture, Ilorin, 25 October 1985.

Akinsanya, A. A. (2000). The 1999 Constitution and the Consolidation of Democracy in Nigeria. In E. U. Okon (Ed.), Civil Society and Consolidation of Democracy in Nigeria. Calabar: CATS Publishers.

Appadorai, A. (2003). The Substance of Politics. New Delhi: Oxford University Press.

Banks, A. S. (1971). Cross-Polity Time Series Archive. Cambridge, MA: MIT Press.

Beetham, D. (1999). Democracy and Human Rights. Cambridge: Polity Press.

Beetham, D., Carvalho, E., Landman, T., \& Weir, S. (2008). Assessing the Quality of Democracy: A Practical Guide. Stockholm: International IDEA.

Brandal, N., Bratberg, Ø., \& Thorsen, D. (2013). The Nordic Model of Social Democracy. London: Palgrave Macmillan. https://doi.org/10.1057/9781137013279

Collier, D., \& Levitsky, S. (1997). Democracy with Adjectives: Conceptual Innovation in Comparative Politics. World Politics, 49, 430-451.

https://doi.org/10.1353/wp.1997.0009

Coppedge, M. (2012). Democratization and Research Methods. Cambridge: Cambridge University Press. https://doi.org/10.1017/CBO9781139016179

Coppedge, M., Lindberg, S., \& Skaaning, S.-E. (2016). Measuring High Level Democratic Principles Using the V-Dem Data. International Political Science Review, 37, 580-593. https://doi.org/10.1177/0192512115622046

Doorenspleet, R. (2005). The Fourth Wave of Democratization: Identification and Explanation. Doctoral Dissertation, Leiden: University of Leiden.

Foweraker, J., \& Kznaric, R. (2000). Measuring Liberal Democratic Performance: An Empirical and Conceptual Critique. Political Studies, 48, 759-787.

https://doi.org/10.1111/1467-9248.00282

Helliwell, J. (1994). Empirical Linkages between Democracy and Economic Growth. British Journal of Political Science, 24, 225-248. https://doi.org/10.1017/S0007123400009790

Hill, D. (2016). Democracy and the Concept of Personal Integrity Rights. The Journal of politics, 78, 822-835. https://doi.org/10.1086/685450

Humana, C. (1983). World Human Rights Guide. London: Hutchinson.

Iwe, N. S. S. (1986). The History and Contents of Human Rights. New York: Peter Lang 
Publishing, Inc.

Jega, A. M. (2008). Democracy, Good Governance and Development in Nigeria. Abuja: Spectrum Books Limited.

Koch, I. E. (2005). Dichotomies, Trichotomies, or Waves of Duties? Human Rights Law Review, 5, 81-103. https://doi.org/10.1093/hrlrev/ngi004

Landman, T. (2005b). Protecting Human Rights: A Global Comparative Study. Washington DC: Georgetown University Press.

Landman, T. (2006). Studying Human Rights. Oxford and New York: Routledge.

Landman, T. (2013). Human Rights and Democracy: The Precarious Triumph of Ideals. London: Bloomsbury Academic.

Landman, T. (2016). Democracy and Human Rights: Explaining Variation in the Record. In J. Foweraker, \& D. Trevizo (Eds.), Democracy and Its Discontents in Latin America (pp. 121-132). Boulder, CO: Lynne Rienner.

Landman, T., \& Carvalho, E. (2009). Measuring Human Rights. London and Oxford: Routledge. https://doi.org/10.4324/9780203867594

Landman, T., \& Häusermann, J. (2003). Map-Making and Analysis of the Main International Initiatives in Developing Indicators of Democracy and Good Governance. Luxembourg: Eurostat.

Landman, T., \& Kersten, L. (2016). Measuring Human Rights. In M. Goodhart (Ed.), Human Rights: Politics and Practice (3rd ed., pp. 127-144). New York: Oxford University Press.

Macpherson, C. B. (1973). Democratic Theory: Essays in Retrieval. Oxford: Clarendon Press.

Munck, G. L. (2009). Measuring Democracy: A Bridge between Scholarship and Politics. Baltimore, MD: Johns Hopkins University Press.

Ofoegbu, J. U. (2013). The Place of Human Rights in Nigeria's Democracy. OGIRISI: A New Journal of African Studies, 10, 60-78. https://doi.org/10.4314/og.v10i1.4

Ogoloma, F., \& Nyege, B. S. (2014). Democracy, Good Governance and Human Rights in Nigeria: An Appraisal. Knowledge Review, 31, 15-23.

Ogundele, B. (1985). The Denied Rights. Nigerian Tribune, September 7th.

Ojo, O. O. (2006). Human Rights and Sustainable Democracy in Nigeria (1999-2003). Journal of Social Sciences, 13, 15-29. https://doi.org/10.1080/09718923.2006.11892526

Ozoigbo, B. I. (2017). Democracy and Human Rights in Nigeria: A Critical Inquiry. Global Journal of Arts, Humanities and Social Sciences, 5, 25-31.

Przeworski, A. (1985). Capitalism and Social Democracy. Cambridge: Cambridge University Press. https://doi.org/10.1017/CBO9781139171830

Przeworski, A., Alvarez, M. E., Cheibub, J. A., \& Limongi, F. (2000). Democracy and Development: Political Institutions and Well-Being in the World, 1950-1990. Cambridge: Cambridge University Press. https://doi.org/10.1017/CBO9780511804946

Sørensen, G. (1993). Democracy and Democratization. Cambridge: Cambridge University Press. 